Prepared in cooperation with the lowa Department of Transportation and the lowa Highway Research Board (Project HR-140)

\title{
Flood of August 24-25, 2016, Upper lowa River and Turkey River, Northeastern lowa
}

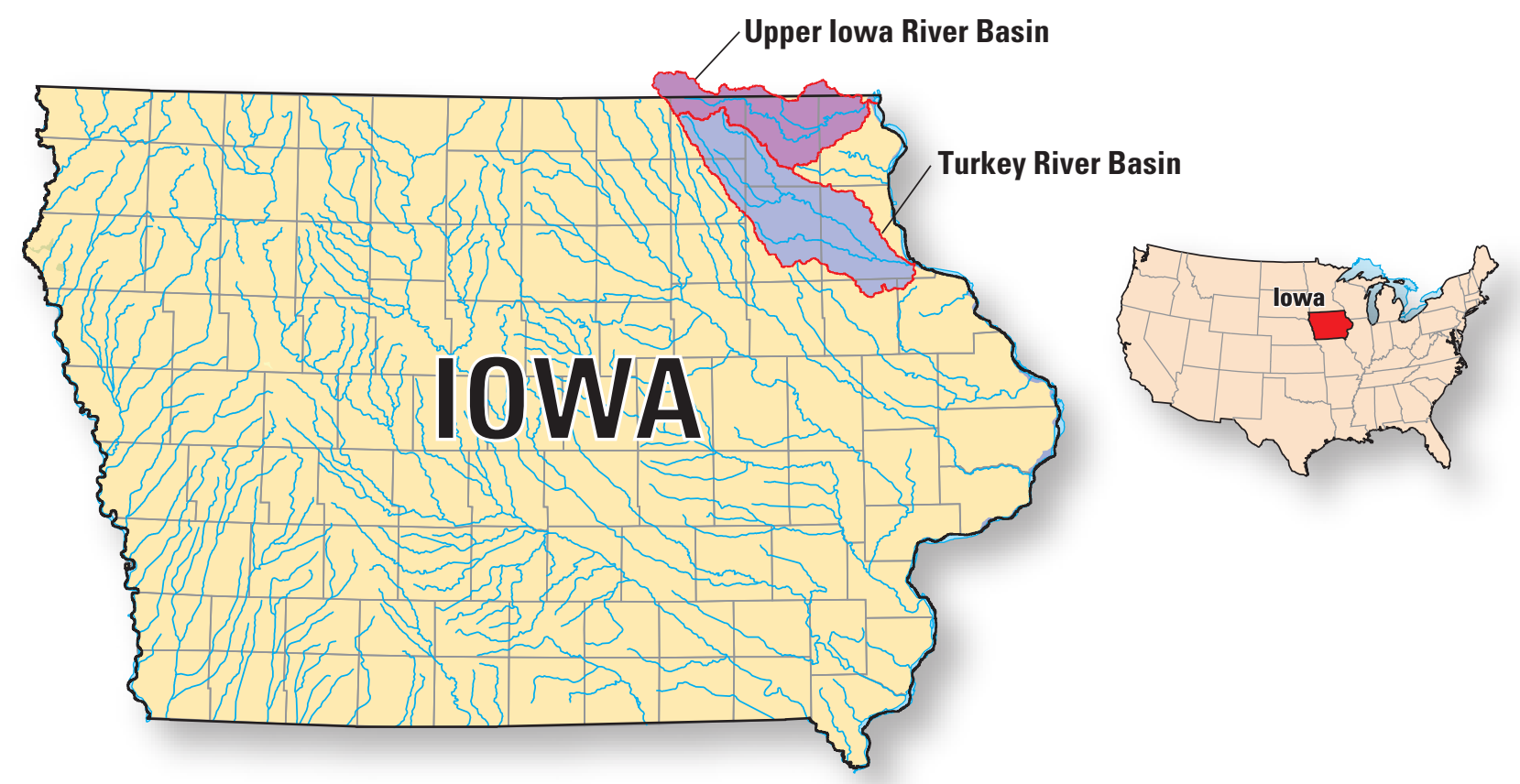

Open-File Report 2017-1128 



\section{Flood of August 24-25, 2016, Upper lowa River and Turkey River, Northeastern lowa}

By S. Mike Linhart and Padraic S. 0'Shea

Prepared in cooperation with the lowa Department of Transportation and the lowa Highway Research Board (Project HR-140)

Open-File Report 2017-1128 


\title{
U.S. Department of the Interior \\ RYAN K. ZINKE, Secretary
}

\section{U.S. Geological Survey William H. Werkheiser, Deputy Director exercising the authority of the Director}

\author{
U.S. Geological Survey, Reston, Virginia: 2018
}

For more information on the USGS - the Federal source for science about the Earth, its natural and living resources, natural hazards, and the environment-visit https://www.usgs.gov or call 1-888-ASK-USGS.

For an overview of USGS information products, including maps, imagery, and publications, visit https://store.usgs.gov.

Any use of trade, firm, or product names is for descriptive purposes only and does not imply endorsement by the U.S. Government.

Although this information product, for the most part, is in the public domain, it also may contain copyrighted materials as noted in the text. Permission to reproduce copyrighted items must be secured from the copyright owner.

Suggested citation:

Linhart, S.M., and O'Shea, P.S., 2018, Flood of August 24-25, 2016, Upper lowa River and Turkey River, northeastern lowa: U.S. Geological Survey Open-File Report 2017-1128, 20 p. with appendix, https://doi.org/10.3133/ofr20171128.

ISBN 978-1-4113-4201-9

ISSN 0196-1497 (print)

ISSN 2331-1258 (online) 


\section{Acknowledgments}

The authors express their gratitude to Harry J. Hillaker, State Climatologist, lowa Department of Agriculture and Land Stewardship, for providing an isohyetal map of rainfall for the 24-hour period ending 12:00 p.m. on August 24, 2016.

The authors also recognize U.S. Geological Survey employees Dave Eash, Roger Haschemeyer, Alex Laffoon, Jason McVay, Sophie Pierce, and Chris Rasmussen for collecting field data for the determination of water-surface and bench-mark elevations listed in this report. 


\section{Contents}

Acknowledgments …….................................................................................................................

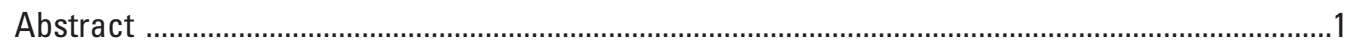

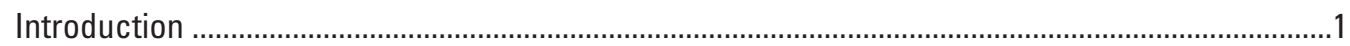

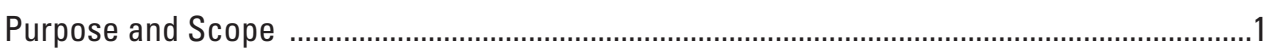

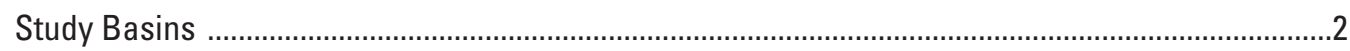

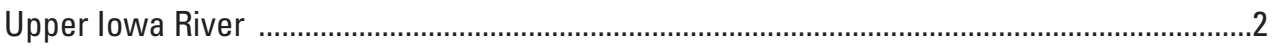

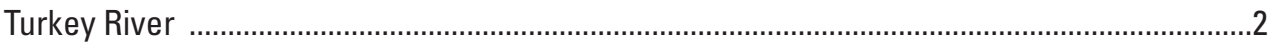

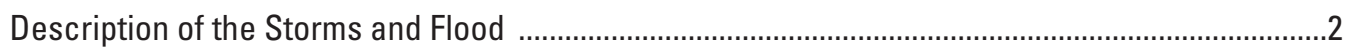

Storm Timeline ......................................................................................................................

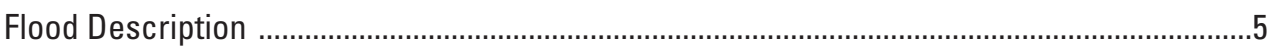

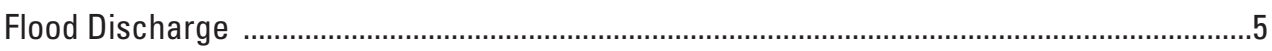

Annual Exceedance Probabilities ............................................................................................

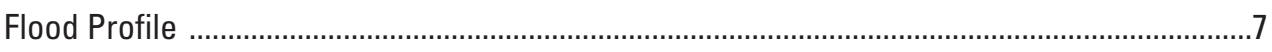

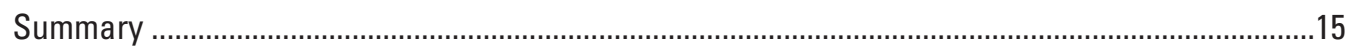

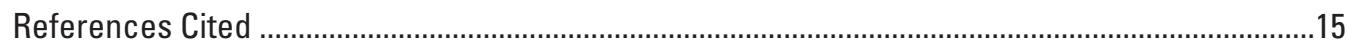

Appendix 1. List of Bench Marks and Reference Points ...........................................................17

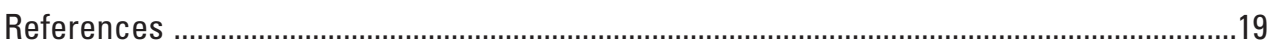

\section{Figures}

1. Map showing the upper lowa River Basin and lines of equal rainfall for 24 hours ending at 12 p.m., August 24, 2016, northeastern lowa ................................................. 3

2. Map showing the Turkey River Basin and lines of equal rainfall for 24 hours ending at 12 p.m., August 24, 2016, northeastern lowa

3. Hydrographs showing discharge and annual exceedance probabilities for $A$, the Upper lowa River near Dorchester, lowa; $B$, the Turkey River at Spillville, lowa; and $C$, the Turkey River near Eldorado, lowa; August 23-27, 2016 ................................. 6

4. Graph showing profile of the August 24-25, 2016, flood in the Upper lowa River, river miles 3-19, northeastern lowa .................................................................................. 9

5. Graph showing profile of the August 24-25, 2016, flood in the Turkey River, river miles 59-118, northeastern lowa ............................................................................. 10

6. Graph showing profile of the August 24-25, 2016, flood in the Turkey River, river

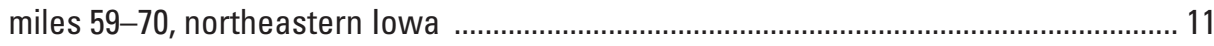

7. Graph showing profile of the August 24-25, 2016, flood in the Turkey River, river miles 70-90, northeastern lowa .............................................................................. 12

8. Graph showing profile of the August 24-25, 2016, flood in the Turkey River, river miles $90-110$, northeastern lowa

9. Graph showing profile of the August 24-25, 2016, flood in the Turkey River, river miles 110-118, northeastern lowa 


\section{Tables}

1. Maximum stages and discharges and corresponding annual exceedance-probability ranges for selected peak flows at streamgages in the Upper lowa River and Turkey River Basins, northeastern lowa

2. Annual exceedance-probability and equivalent flood-recurrence interval for selected probabilities

3. Locations and elevations of high-water marks used in the Upper lowa River flood profile, flood of August 24-25, 2016, northeastern lowa

4. Locations and elevations of high-water marks used in the Turkey River flood profile, flood of August 24-25, 2016, northeastern lowa

$1-1$. Bench marks and reference points used in the Upper lowa River and Turkey River flood profiles, flood of August 24-25, 2016, northeastern lowa 


\section{Conversion Factors}

U.S. customary units to International System of Units

\begin{tabular}{|c|c|c|}
\hline Multiply & By & To obtain \\
\hline \multicolumn{3}{|c|}{ Length } \\
\hline inch (in.) & 2.54 & centimeter $(\mathrm{cm})$ \\
\hline foot $(\mathrm{ft})$ & 0.3048 & meter (m) \\
\hline mile (mi) & 1.609 & kilometer $(\mathrm{km})$ \\
\hline \multicolumn{3}{|c|}{ Area } \\
\hline square mile $\left(\mathrm{mi}^{2}\right)$ & 2.590 & square meter $\left(\mathrm{m}^{2}\right)$ \\
\hline \multicolumn{3}{|c|}{ Flow rate } \\
\hline cubic foot per second $\left(\mathrm{ft}^{3} / \mathrm{s}\right)$ & 0.02832 & cubic meter per second $\left(\mathrm{m}^{3} / \mathrm{s}\right)$ \\
\hline
\end{tabular}

\section{Datum}

Elevation or vertical coordinate information is referenced to the National Geodetic Vertical Datum of 1929 (NGVD 29). Elevation refers to distance above or below NGVD 29. NGVD 29 can be converted to the North American Vertical Datum of 1988 by using the National Geodetic Survey conversion utility available at http://www.ngs.noaa.gov/TOOLS/Vertcon/vertcon.html.

Horizontal coordinate information is referenced to the North American Datum of 1983 (NAD 83).

\section{Supplemental Information}

Water year is the 12-month period from 0ctober 1 through September 30 . The water year is designated by the calendar year in which the water year ends and that includes 9 of the 12 months. Thus, the water year beginning on October 1, 2015, and ending September 30, 2016, is called the "2016 water year." 


\title{
Flood of August 24-25, 2016, Upper lowa River and Turkey River, Northeastern lowa
}

\author{
By S. Mike Linhart and Padraic S. O'Shea
}

\section{Abstract}

Major flooding occurred August 24-25, 2016, in the Upper Iowa River Basin and Turkey River Basin in northeastern Iowa following severe thunderstorm activity over the region. About 8 inches of rain were recorded for the 24-hour period ending at 4 p.m., August 24, at Decorah, Iowa, and about 6 inches of rain were recorded for the 24-hour period ending at 7 a.m., August 24, at Cresco, Iowa, about 14 miles northwest of Spillville, Iowa. A maximum peak-of-record discharge of 38,000 cubic feet per second in the Upper Iowa River at streamgage 05388250 Upper Iowa River near Dorchester, Iowa, occurred on August 24, 2016, with an annual exceedance-probability range of $0.2-1$ percent. High-water marks were measured at six locations along the Upper Iowa River between State Highway 26 near the mouth at the Mississippi River and State Highway 76 about 3.5 miles south of Dorchester, Iowa, a distance of 15 river miles. Along the profiled reach of the Turkey River, a maximum peak-of-record discharge of 15,300 cubic feet per second at streamgage 05411600 Turkey River at Spillville, Iowa, occurred on August 24, 2016, with an annual exceedance-probability range of 1-2 percent. A maximum peak discharge of 35,700 cubic feet per second occurred on August 25, 2016, along the profiled reach of the Turkey River at streamgage 05411850 Turkey River near Eldorado, Iowa, with an annual exceedance-probability range of $0.2-1$ percent. High-water marks were measured at 11 locations along the Turkey River between County Road B64 in Elgin and 220th Street, located about 4.5 miles northwest of Spillville, Iowa, a distance of 58 river miles. The high-water marks were used to develop flood profiles for the Upper Iowa River and Turkey River.

\section{Introduction}

Severe thunderstorms following a wetter than usual summer in northeastern Iowa contributed to record flooding in the Upper Iowa River and Turkey River in northeastern Iowa on August 24-25, 2016. Heavy rainfall totals during a 24-hour period were a result of repeated rounds of thunderstorms during the evening of August 23rd into the morning hours of August 24th (National Centers for Environmental Information, National Oceanic and Atmospheric Administration [NOAA], 2016). As a result, fields were flooded, and highways were closed throughout the basins. Maximum peak discharges of record were measured at one streamgage located along the profiled reach of the Upper Iowa River and at one of the two streamgages located along the profiled reach of the Turkey River.

\section{Purpose and Scope}

This report is part of an ongoing program of documenting large flood events and the effects of selected highways and bridges on flood levels of rivers and streams in Iowa. The program is funded in cooperation with the Iowa Department of Transportation (Iowa DOT) and the Iowa Highway Research Board (Research Board project HR-140). A list of other Iowa flood profile reports can be found in Eash (2014) or can be obtained by accessing https://ia.water.usgs.gov/flood/reports. html.

This report provides information about the thunderstorms and the resulting flooding on August 24-25, 2016, in the Upper Iowa River Basin and the Turkey River Basin. The estimated annual exceedance-probability (AEP) ranges of the flood discharges at one continuous-record streamgage in the Upper Iowa River Basin and two continuous-record streamgages in the Turkey River Basin in the profiled reaches are also described. High-water marks (HWM) at selected sites along the Upper Iowa River are presented in a flood profile from State Highway 26 near the mouth of the Upper Iowa River at the Mississippi River to State Highway 76 south of Dorchester, Iowa, a distance of 15 river miles (mi). The HWMs at selected sites along the Turkey River are presented in a flood profile from County Road B64 in Elgin, Iowa, to 220th Street northwest of Spillville, Iowa, a distance of 58 river mi. 


\section{Study Basins}

\section{Upper lowa River}

The Upper Iowa River is a tributary of the Mississippi River in northeastern Iowa (fig. 1). The headwaters are in Mower County, Minnesota, and a small part of Mitchell County, Iowa. The river flows east primarily through Howard, Winneshiek, and Allamakee Counties in Iowa. Short segments of the river lie in Fillmore County, Minnesota, as the river channel meanders across the Iowa/Minnesota border. Northern parts of the basin also lie in Houston County, Minnesota, near the eastern end of the basin. The river mouth is at the Mississippi River in northeastern Allamakee County. The drainage area at the mouth is 999 square miles $\left(\mathrm{mi}^{2}\right)$ (Fischer and Eash, 2010).

The Upper Iowa River Basin lies in two of Iowa's landform regions, the Iowan Surface and the Paleozoic Plateau (Prior, 1991; not shown in fig. 1). The headwaters of the river are on the Iowan Surface; the river crosses onto the Paleozoic Plateau near Lime Springs. The topography of the Iowan Surface "appears slightly inclined to gently rolling with long slopes, low relief, and open views to the horizon" (Prior, 1991). In contrast, the topography of the Paleozoic Plateau "include[s] abundant rock outcroppings, a near absence of glacial deposits, many deep, narrow valleys containing cool, fast-flowing streams, and more woodlands" (Prior, 1991). In the eastern one-half of Allamakee County, the Upper Iowa River flood plain becomes wide and flat before the river empties into the Mississippi River. More extensive descriptions of the landform regions and physiography of the Upper Iowa River Basin are available from the Iowa Natural Resources Council (1958) and Prior (1991).

Land use in the Upper Iowa River Basin is primarily agricultural in the Iowan Surface landform region and agricultural and forest in the Paleozoic Plateau landform region (Prior, 1991). The Upper Iowa River flows through Decorah, the only urban community in the basin, in Winneshiek County (fig. 1). Parts of the city are protected by levees. The Upper Iowa River is a popular recreation venue for much of its length.

\section{Turkey River}

The Turkey River is a tributary of the Mississippi River in northeastern Iowa. The Turkey River Basin originates in Howard County and flows about $148 \mathrm{mi}$ through the cities of Spillville, Clermont, Elgin, and Elkader to its mouth at the Mississippi River in southeastern Clayton County (fig. 2). The river flows southeast primarily through Howard, Winneshiek, Fayette, and Clayton Counties in Iowa. The drainage area at the mouth is $1,684 \mathrm{mi}^{2}$ (Larimer, 1957).

Most of the Turkey River Basin lies in two of Iowa's landform regions, the Iowan Surface and the Paleozoic Plateau (Prior, 1991; not shown in fig. 2). The northwestern or upper part of the basin drains the low-relief plain of the Iowan Surface landform region (Prior, 1991). Although streams draining the Iowan Surface are well established, stream gradients are low. In Winneshiek and Fayette Counties, the Turkey River Basin crosses from the Iowan Surface landform region to the Paleozoic Plateau landform region. In Clayton County, the southeastern or lower part of the basin drains the Paleozoic Plateau. The bedrock-dominated, erosional topography of the Paleozoic Plateau is characterized by plateau-like uplands, integrated drainage networks with steep gradients, and deeply entrenched valleys (Iowa Natural Resources Council, 1958; Horick, 1989; Prior, 1991). More extensive descriptions of the landform regions and physiography of the Turkey River Basin are available from the Iowa Natural Resources Council (1958) and Prior (1991).

Land use in the Turkey River Basin is primarily agricultural in the Iowan Surface landform region and agricultural, timber, and some livestock operations in the Paleozoic Plateau landform region (Prior, 1991).

\section{Description of the Storms and Flood}

\section{Storm Timeline}

Intense rainfall fell over northeastern Iowa on August 23-24, 2016. Within the Upper Iowa River Basin, the rainfall amount at Decorah was 8.06 inches (in.) for the 24-hour period ending at 4 p.m., August 24; at Cresco, near the boundary of the Upper Iowa River and Turkey River Basins, rainfall was 6.04 in. for the 24-hour period ending at 7 a.m., August 24 (Hillaker, 2016b). One location about 5 mi southeast of Decorah recorded 8.46 in. for the 24-hour period ending at 7 a.m., August 24 (Harry J. Hillaker, State Climatologist, Iowa Department of Agriculture, written commun., 2016). The storms followed a wet period for northeastern Iowa during the first 3 weeks of August. Total rainfall at Decorah for the month of August was $13.84 \mathrm{in}$. and is the second highest total for the 131 years of record at Decorah. The highest was 15.11 in. in 2007 (Hillaker, 2016b). A 24-hour isohyetal map compiled by the Iowa State Climatologist for the period ending at 12 p.m., August 24, 2016, is shown for the Upper Iowa River Basin in figure 1 (Harry J. Hillaker, written commun., 2016).

Within the Turkey River Basin, the rainfall amount at Cresco was 6.04 in. for the 24-hour period ending at 7 a.m., August 24 (Hillaker, 2016b); at Protivin it was 6.89 in. for the 24-hour period ending at 7 a.m., August 24; and for Fort Atkinson it was 6.05 in. for the 24-hour period ending at 7 a.m., August 24, 2016 (Harry J. Hillaker, written commun., 2016). A 24-hour isohyetal map compiled by the Iowa State Climatologist for the period ending at 12 p.m., August 24, 2016, is shown for the Turkey River Basin in figure 2 (Harry J. Hillaker, written commun., 2016). 

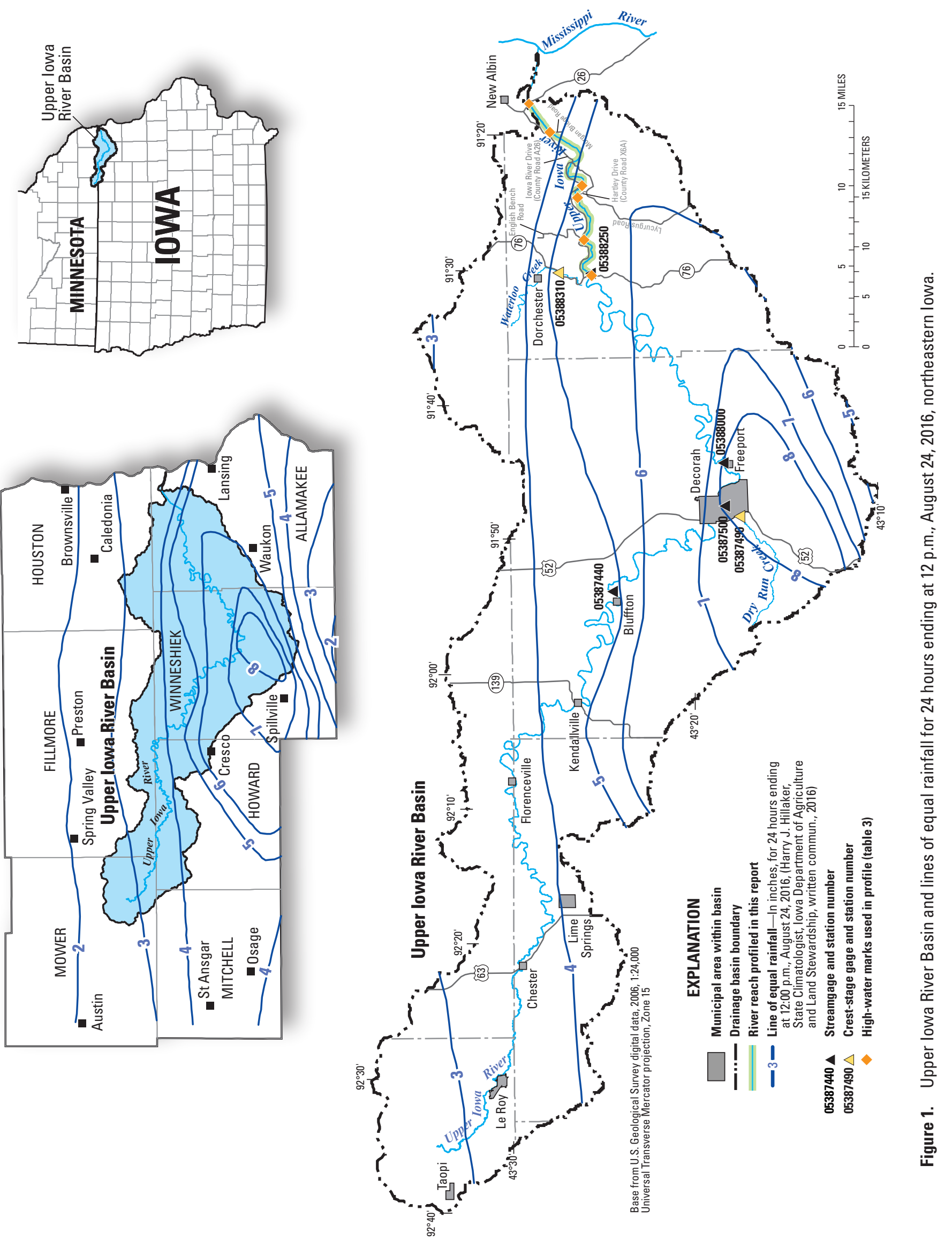


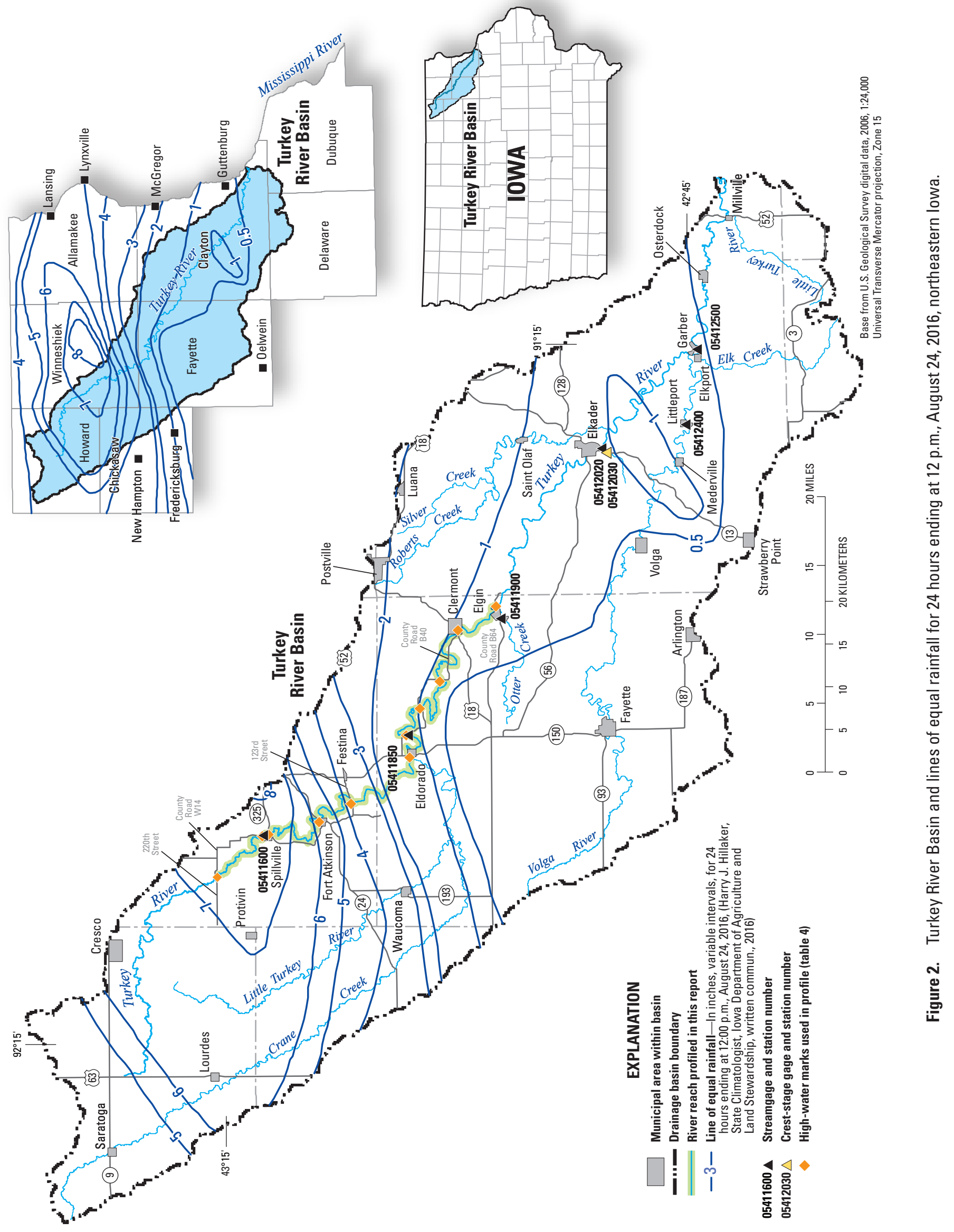




\section{Flood Description}

The intense rainfall caused widespread flooding throughout five counties in northeastern Iowa, August 24-25, 2016. Estimated countywide damage to roads and bridges was about $\$ 480,000$ in Howard County (Nick Rissman, Howard County Engineer, written commun., 2017), \$1.2 million in Winneshiek County (Lee Bjerke, Winneshiek County Engineer, written commun., 2017), and $\$ 40,000$ in Clayton County (Rafe Koopman, Clayton County Engineer, written commun., 2017). In Allamakee County, estimates of damage to secondary county roads and bridges were more than $\$ 570,000$ (Jeremy Bjerke, Allamakee County Engineer, written commun., 2017). In Fayette County, preliminary estimates of damage to roads were $\$ 60,000$ (Love, 2016). On the evening of August 23 in Winneshiek County, there was a lot of street flooding in towns across the county, and numerous roads were closed (National Weather Service [NWS] and NOAA, 2016a). On the morning of August 24, 3 mi east of Protivin, County Road B16 was impassable because of rising water. Also on the morning of August 24, sand bagging efforts were called off in Spillville because of the quickly rising Turkey River, and there were reports of water rescues underway near Waukon in Allamakee County and east of Decorah in Winneshiek County (NWS and NOAA, 2016a). By the end of the day on August 25, the Governor of Iowa had issued a disaster proclamation for 8 counties in northeastern Iowa, and early estimates of damages from the flooding to public infrastructure for Winneshiek County were \$2.4 million and another \$1 million for Decorah (National Centers for Environmental Information, NOAA, 2016). On September 19, the Governor of Iowa requested a major disaster declaration; on September 29, the President of the United States declared that a major disaster exists in the State of Iowa. For the Public Assistance request from the Governor of Iowa, primarily for damage to roads and bridges (that included three additional counties in northeastern Iowa), the cost estimate was more than $\$ 4.5$ million (Federal Emergency Management Agency, 2016).

\section{Flood Discharge}

Along the profiled reach of the Upper Iowa River (fig. 1), a maximum peak-of-record discharge of 38,000 cubic feet per second $\left(\mathrm{ft}^{3} / \mathrm{s}\right)$ at the continuous-record streamgage 05388250 Upper Iowa River near Dorchester, Iowa, occurred on August 24, 2016 (U.S. Geological Survey [USGS], 2016a). Along the profiled reach of the Turkey River (fig. 2), a maximum peak-of-record discharge of $15,300 \mathrm{ft}^{3} / \mathrm{s}$ at the continuousrecord streamgage 05411600 Turkey River at Spillville, Iowa, occurred on August 24, 2016 (USGS, 2016b). The discharge hydrographs for August 23-27, 2016, are shown for these two streamgages (figs. $3 A$ and $3 B$ ), as well as the streamgage 05411850 Turkey River near Eldorado, Iowa, (fig. $3 \mathrm{C}$ ), which also is located along the profiled reach of the Turkey River (fig. 2). The peak discharge of 35,700 ft/s for streamgage 05411850 Turkey River near Eldorado, Iowa, on August 25, 2016, was the second highest peak discharge of record (USGS, 2016c). The maximum peak discharge of record for streamgage 05411850 Turkey River near Eldorado was $50,100 \mathrm{ft}^{3} / \mathrm{s}$ on June 9, 2008 (USGS, 2008). The peak discharges at the streamgages were determined from rating curves that were verified by discharge measurements made near the time of occurrence of the respective peaks.

\section{Annual Exceedance Probabilities}

The 2016 flood-peak discharges for the three streamgages are listed in table 1. Selected prior-year peak discharges are included in the table for comparison purposes. Also included in table 1 are AEP ranges for the maximum peak discharges at the Upper Iowa River streamgage and the two Turkey River streamgages. The AEP is an estimate of the likelihood of a flood of specific magnitude occurring in any 1 year, and AEP range expresses the uncertainty of estimating precise exceedance probabilities. The reporting ranges are greater than 10 percent, $4-10$ percent, $2-4$ percent, $1-2$ percent, $0.2-1$ percent, and less than 0.2 percent (Eash, 2001). The range is determined by the estimated AEP discharges that bracket the observed flood-peak discharge. If the observed peak discharge is the same value as an estimated AEP discharge, the lower AEP range is used.

The estimated 4-, 2-, 1-, and 0.2-percent AEP discharges at streamgages 05388250 Upper Iowa River near Dorchester, 05411600 Turkey River at Spillville, and 05411850 Turkey River near Eldorado are shown in figure 3 as horizontal lines; the AEP ranges are the areas between the lines. The probability discharges at the three streamgages were calculated using the Weighting of Independent Estimates (WIE) program (Cohn and others, 2012) following guidelines in appendix 8 of Bulletin 17B (Interagency Advisory Committee on Water Data, 1982).

Exceedance probabilities formerly were reported as flood probabilities, or flood-recurrence intervals, expressed in years. For example, a 1-percent exceedance-probability discharge is the same as the 100-year recurrence-interval flood discharge. Because of confusion caused over the years by two or more "100-year floods" occurring in a period of much less than 100 years, the scientific and engineering community has begun expressing the annual likelihood of occurrence of flood discharges as a probability (Holmes and Dinicola, 2010). Percent probability is the inverse of the recurrence interval multiplied by 100 . Selected AEPs and equivalent flood-recurrence intervals are listed in table 2.

For informational purposes, discharges corresponding to National Weather Service (NWS) designated flood stages (fig. 3) are also shown on the hydrographs. The flood stages represent "Minor flooding - minimal or no property damage, but possibly some public threat" (NWS and NOAA, 2017). The discharges corresponding to the NWS flood stages were determined from the respective USGS stage-discharge rating curves in use at the time of the flood. At streamgage 05388250 Upper Iowa River near Dorchester, Iowa, the NWS flood 

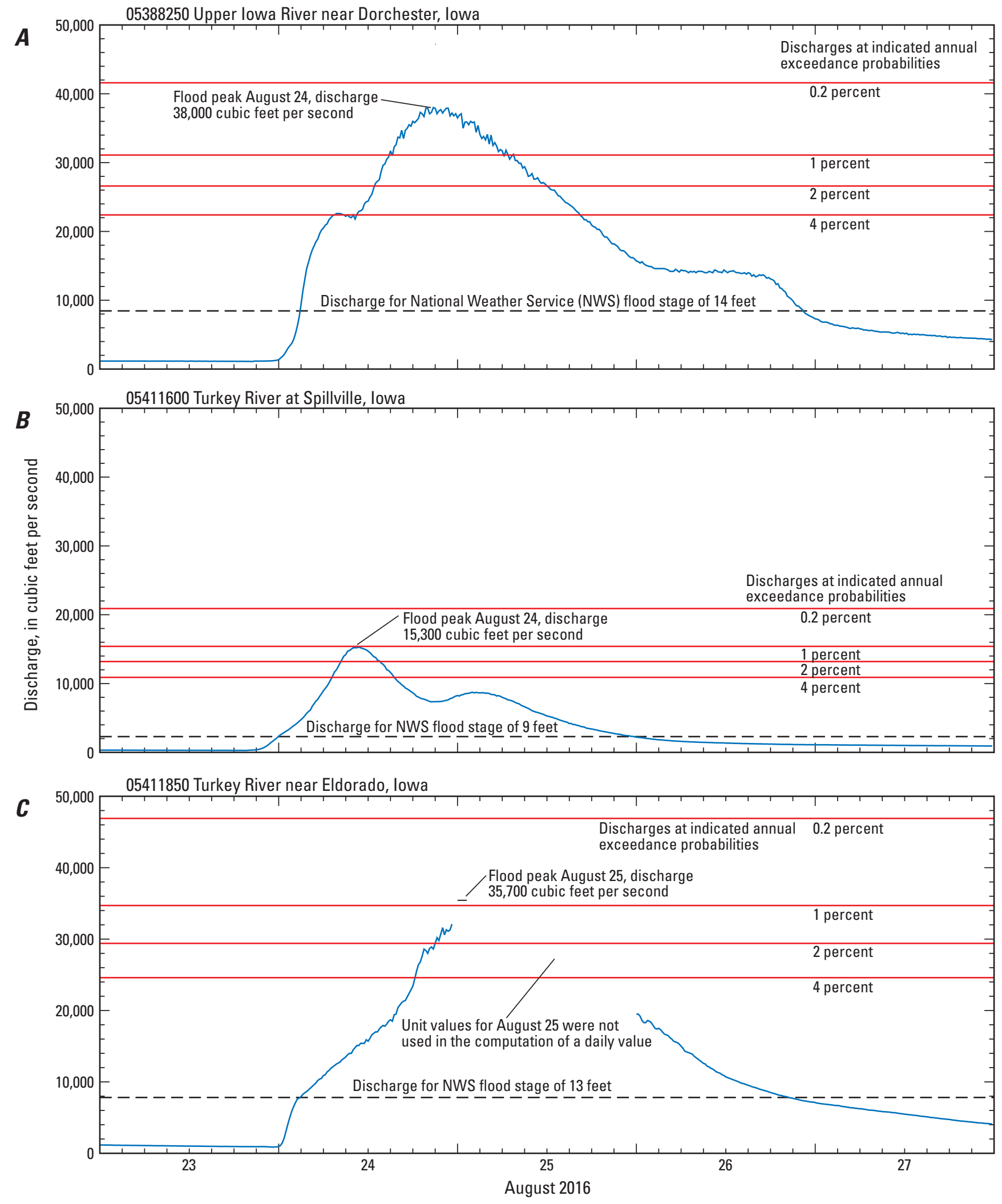

Figure 3. Hydrographs showing discharge and annual exceedance probabilities for $A$, the Upper lowa River near Dorchester, lowa; $B$, the Turkey River at Spillville, lowa; and C, the Turkey River near Eldorado, lowa; August 23-27, 2016. 
Table 1. Maximum stages and discharges and corresponding annual exceedance-probability ranges for selected peak flows at streamgages in the Upper lowa River and Turkey River Basins, northeastern lowa.

[AEP, annual exceedance probability; $\mathrm{mi}^{2}$, square mile; $\mathrm{ft}$, foot; $\mathrm{ft}^{3} / \mathrm{s}$, cubic foot per second; <, less than]

\begin{tabular}{|c|c|c|c|c|c|c|}
\hline Streamgage number and name & $\begin{array}{l}\text { Peak-flow record } \\
\text { (water years) }\end{array}$ & $\begin{array}{c}\text { Drainage area } \\
\left(\mathrm{mi}^{2}\right)\end{array}$ & Date of peak & $\begin{array}{c}\text { Peak stage } \\
\text { (ft) }\end{array}$ & $\begin{array}{l}\text { Peak discharge } \\
\left(\mathrm{ft}^{3} / \mathbf{s}\right)\end{array}$ & $\begin{array}{c}\text { AEP range }{ }^{1} \\
\text { (percent) }\end{array}$ \\
\hline \multicolumn{7}{|c|}{ Upper lowa River Basin } \\
\hline \multirow{3}{*}{$\begin{array}{l}05388250 \text { Upper Iowa River } \\
\text { near Dorchester, Iowa }\end{array}$} & \multirow{3}{*}{$\begin{array}{l}1941,1976-95 \\
1997-2016\end{array}$} & \multirow[t]{3}{*}{770} & $5 / 31 / 1941$ & 21.80 & ${ }^{2} 30,400$ & $1-2$ \\
\hline & & & $6 / 9 / 2008$ & 22.46 & 31,200 & $0.2-1$ \\
\hline & & & $8 / 24 / 2016$ & 24.30 & 38,000 & $0.2-1$ \\
\hline \multicolumn{7}{|c|}{ Turkey River Basin } \\
\hline \multirow{3}{*}{$\begin{array}{l}05411600 \text { Turkey River at } \\
\text { Spillville, Iowa }\end{array}$} & \multirow{3}{*}{$\begin{array}{l}1947,1956-73 \\
1978-91,2010-16\end{array}$} & \multirow[t]{3}{*}{177} & $6 /-/ 1947$ & ${ }^{3} 18.40$ & ${ }^{2,4} 10,000$ & $4-10$ \\
\hline & & & $7 / 12 / 1972$ & 16.73 & 8,600 & $4-10$ \\
\hline & & & $8 / 24 / 2016$ & 20.25 & 15,300 & $1-2$ \\
\hline \multirow{3}{*}{$\begin{array}{l}05411850 \text { Turkey River near } \\
\text { Eldorado, Iowa }\end{array}$} & \multirow{3}{*}{$2001-16$} & \multirow[t]{3}{*}{641} & $6 / 9 / 2008$ & 21.46 & 50,100 & $<0.2$ \\
\hline & & & $6 / 20 / 2014$ & 18.92 & 28,800 & $2-4$ \\
\hline & & & $8 / 25 / 2016$ & ${ }^{3} 21.34$ & 35,700 & $0.2-1$ \\
\hline
\end{tabular}

${ }^{1}$ Annual exceedance-probability (AEP) ranges reflect the uncertainty of estimating flood-frequency discharges. The exceedance probability is calculated using established techniques but then reported in one of the following ranges: greater than 10 percent, $4-10$ percent, 2-4 percent, 1-2 percent, $0.2-1$ percent, and less than 0.2 percent. Unless noted otherwise, AEP ranges are based on a weighted average of two independent frequency estimates. The Weighting of Independent Estimates (WIE) program was used to estimate the AEP following guidelines in appendix 8 of Bulletin 17B (Interagency Advisory Committee on Water Data, 1982; Cohn and others, 2012). The WIE program uses the variance and estimate of the Bulletin 17B streamgage-probablity analysis and the variance and estimate of the regional-regression AEP calculation (Eash, 2001) to compute a weighted probability estimate and variance at a streamgage.

${ }^{2}$ Discharge is a historic peak. Historic peaks are events that occur outside periods of systematic data collection.

${ }^{3}$ Gage height determined from floodmark.

${ }^{4}$ Discharge is an estimate.

Table 2. Annual exceedance-probability and equivalent floodrecurrence interval for selected probabilities.

\begin{tabular}{cc}
\hline $\begin{array}{c}\text { Annual exceedance-probability } \\
\text { (percent) }\end{array}$ & $\begin{array}{c}\text { Flood-recurrence interval } \\
\text { (years) }\end{array}$ \\
\hline 20 & 5 \\
10 & 10 \\
4 & 25 \\
2 & 50 \\
1 & 100 \\
0.5 & 200 \\
0.2 & 500 \\
\hline
\end{tabular}

stage is $14 \mathrm{ft}$ (NWS and NOAA, 2016b), and the discharge is $8,280 \mathrm{ft}^{3} / \mathrm{s}$ (USGS, 2017a). At streamgage 05411600 Turkey River at Spillville, Iowa, the NWS flood stage is $9 \mathrm{ft}$ (NWS and NOAA, 2016c), and the discharge is $2,290 \mathrm{ft}^{3} / \mathrm{s}$ (USGS, 2017b). At streamgage 05411850 Turkey River near Eldorado, Iowa, the NWS flood stage is $13 \mathrm{ft}$ (NWS and NOAA, 2016d), and the discharge is $7,820 \mathrm{ft}^{3} / \mathrm{s}$ (USGS, 2017c).

\section{Flood Profile}

The USGS located and measured the elevations of HWMs at six locations along the Upper Iowa River to develop a flood profile (fig. 1 and table 3). The profile is about 15 river miles from State Highway 26 near the mouth of the Upper Iowa River at the Mississippi River to State Highway 76 south of Dorchester, Iowa. The HWM locations include all State numbered highway bridges and several county and local road bridges.
The USGS also located and measured the elevations of HWMs at 11 locations along the Turkey River to develop a flood profile (fig. 2 and table 4). The profile is about 58 river miles from County Road B64 in Elgin, Iowa, to 220th Street located about 4.5 miles northwest of Spillville, Iowa. The HWM locations include all Federal and State numbered highway bridges and several county and local road bridges.

The HWMs were located and flagged within 3 days of the flood and surveyed to a bench mark at each location within 30 days. The HWMs were flagged on the upstream and downstream sides of the bridges. The upstream marks were located about one bridge length from the bridge to avoid drawdown effects from channel contraction, and the downstream marks were located immediately downstream from the bridge. Bridge deck, bridge low-chord, and low-flow reference-point elevations also were measured with respect to the bench marks. The low-flow reference points were established so that watersurface elevations could be measured during a period when the streamflow was not directly affected by rainfall from which a low-flow profile was constructed. All elevations were subsequently referenced to the National Geodetic Vertical Datum of 1929 (NGVD 1929) by surveying level lines to the bench marks from other established bench marks or by using Global Positioning System (GPS) technology. The bench marks and reference points used in this study and a brief discussion regarding the elevation-measurement methods are presented in an appendix to this report.

The locations of the HWMs were measured in river miles from the mouths of the Upper Iowa River and the Turkey River at the Mississippi River. The distances to many locations were determined in a previous study (Eash, 2003). In 
Table 3. Locations and elevations of high-water marks used in the Upper lowa River flood profile, flood of August 24-25, 2016, northeastern lowa.

[HWM, high-water mark; NGVD 29, National Geodetic Vertical Datum of 1929; ND, not determined; USGS, U.S. Geological Survey]

\begin{tabular}{cllc}
\hline $\begin{array}{c}\text { Distance from mouth } \\
\text { (river miles) }\end{array}$ & \multicolumn{1}{c}{$\begin{array}{c}\text { Location } \\
\text { (feet above NGVD 29) }\end{array}$} & $\begin{array}{c}\text { Upstream HWM } \\
\text { (feet above NGVD 29) }\end{array}$ \\
\hline 3.25 & State Highway 26, south of New Albin & 636.07 & 637.31 \\
5.44 & Ray's Landing at Morgan Bridge Road & 642.17 \\
10.94 & $\begin{array}{l}\text { Lycurgus Road (County Road X20), adjacent to intersection with Iowa River Drive } \\
\text { (County Road A26) }\end{array}$ & 660.40 \\
12.01 & Hartley Drive (County Road X6A) & 661.19 \\
15.24 & English Bench Road at intersection with Iowa River Drive (County Road A26) & 664.17 \\
18.28 & USGS streamgage 05388250, State Highway 76, south of Dorchester & 672.83 \\
\hline
\end{tabular}

Table 4. Locations and elevations of high-water marks used in the Turkey River flood profile, flood of August 24-25, 2016, northeastern lowa.

[HWM, high-water mark; NGVD 29, National Geodetic Vertical Datum of 1929; USGS, U.S. Geological Survey]

\begin{tabular}{|c|c|c|c|}
\hline $\begin{array}{l}\text { Distance from mouth } \\
\text { (river miles) }\end{array}$ & Location & $\begin{array}{c}\text { Downstream HWM } \\
\text { (feet above NGVD 29) }\end{array}$ & $\begin{array}{c}\text { Upstream HWM } \\
\text { (feet above NGVD 29) }\end{array}$ \\
\hline 59.65 & County Road B64, Elgin & 806.43 & 807.27 \\
\hline 64.38 & U.S. Highway 18, Clermont & 832.77 & 834.20 \\
\hline 71.90 & County Road B40, northwest of Clermont & 866.18 & 867.85 \\
\hline 78.22 & County Road B40, southeast of Eldorado & 893.57 & 894.18 \\
\hline 83.59 & USGS streamgage 05411850 , County Road B40, east of Eldorado & 911.34 & 912.57 \\
\hline 87.06 & State Highway 150, Eldorado & 928.36 & 931.02 \\
\hline 95.19 & 123rd Street, west of Festina & 977.70 & 978.43 \\
\hline 101.14 & State Highway 24, Fort Atkinson & $1,011.26$ & $1,013.63$ \\
\hline 110.30 & State Highway 325 , Spillville & $1,051.92$ & $1,053.57$ \\
\hline 110.82 & USGS streamgage 05411600 , County Road W14, Spillville & $1,057.03$ & $1,057.20$ \\
\hline 117.95 & 220th Street, northwest of Spillville & $1,082.75$ & $1,083.82$ \\
\hline
\end{tabular}

cases where the HWMs were measured at previously unknown distances, the distances were determined for the locations using a geographic information system (GIS) using the USGS National Hydrography Dataset (NHD) data (USGS, 2017d). The HWM locations and elevations for the Upper Iowa River are listed in table 3. The HWM locations and elevations for the Turkey River are listed in table 4. The HWMs in these tables and in the profiles (figs. 4-9) are an average of multiple upstream or downstream HWMs measured at each location.

The HWMs along the Upper Iowa River are plotted in a flood profile in figure 4 . The locations are annotated along the bottom. The line connecting the HWMs in figure 4 approximates the high-water surface between the marks. This line does not account for any features between the surveyed HWM locations that may have affected high-water elevations during the flood, such as channel morphology and bridges where HWMs were not measured. For comparison purposes, the profile from the June 8-9, 2008, flood also is shown. The lower line in the figures represents approximate low-flow conditions and connects the water-surface elevations that were measured November 17, 2008 (Fischer and Eash, 2010). The low-flow line also approximates the water surface between measurement locations.

The HWMs along the Turkey River are plotted in a flood profile in figure 5 . The profile is expanded in figures 6-9, where the locations are annotated. The line connecting the HWMs in the figures approximates the high-water surface between the marks. For comparison purposes, the profiles of the floods of June 15, 1991 (Eash and Koppensteiner, 1996), and the floods of March 19, 1979 (Iowa Natural Resources Council, 1980), are shown in figures 5-7. The profile of the July 12, 1972, flood (Eash and Koppensteiner, 1996) is also shown in figure 5 and figures 7-9. The lower lines in the figures represent approximate low-flow conditions and connect the water-surface elevations that were measured December 1, 2016 (figs. 5-9), September 21, 1992 (figs. 5-7) (Eash and Koppensteiner, 1996), and July 1-2, 1981 (figs. 5 and 7-9) (Eash and Koppensteiner, 1996). The low-flow line also approximates the water surface between measurement locations.

Only bridges where HWMs were measured are shown in the figures. They are symbolized by an I-beam symbol where the bottom flange represents the lowest elevation of the low chord and the top flange represents the elevation of the bridge deck above the lowest low chord. The vertical lines along the bottom of the figures also show locations of roads and bridges where HWMs were measured. Selected notable landmarks and other sites where HWMs were measured in previous studies are also shown for reference. 


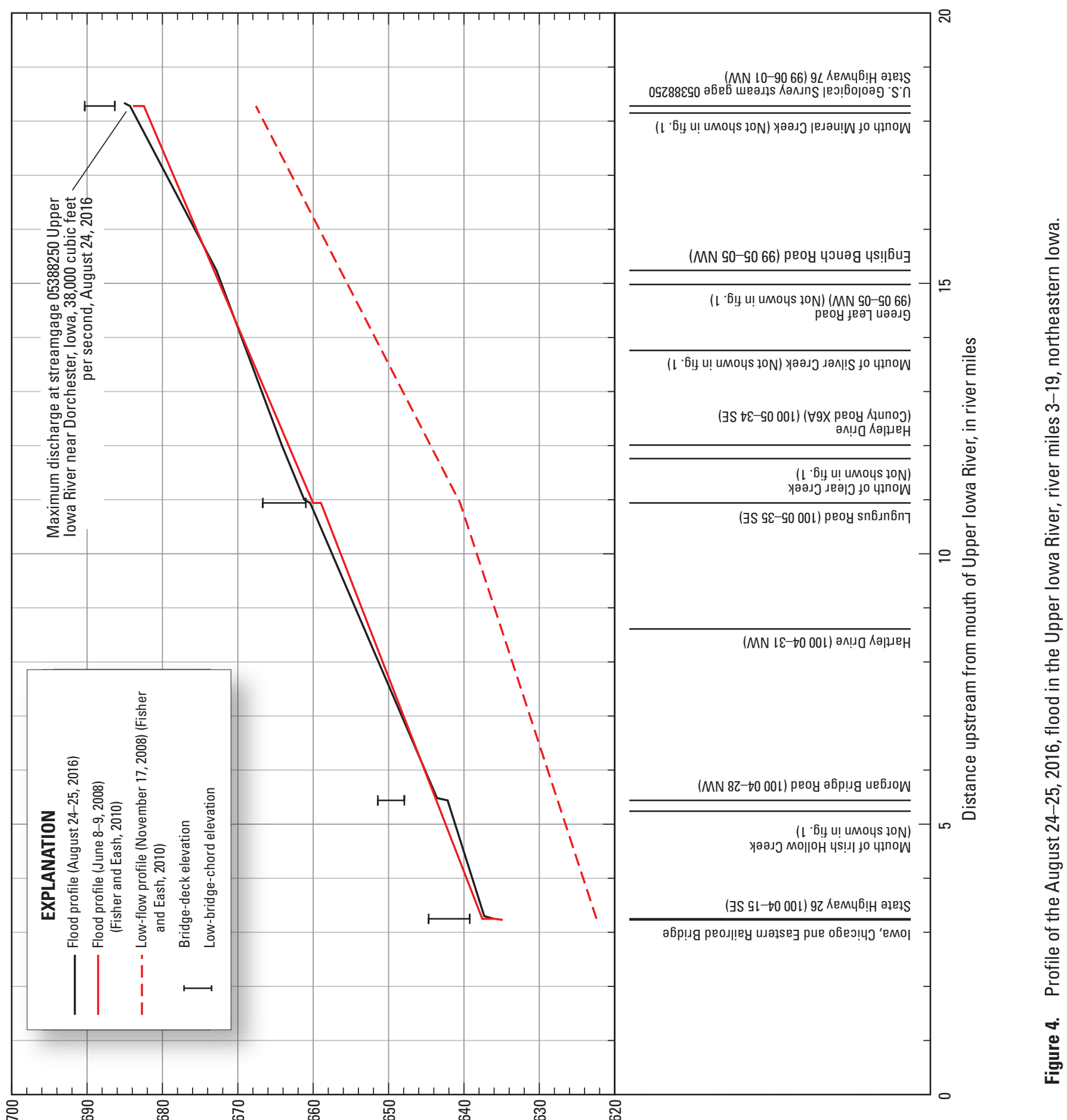

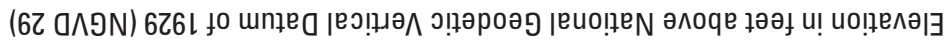




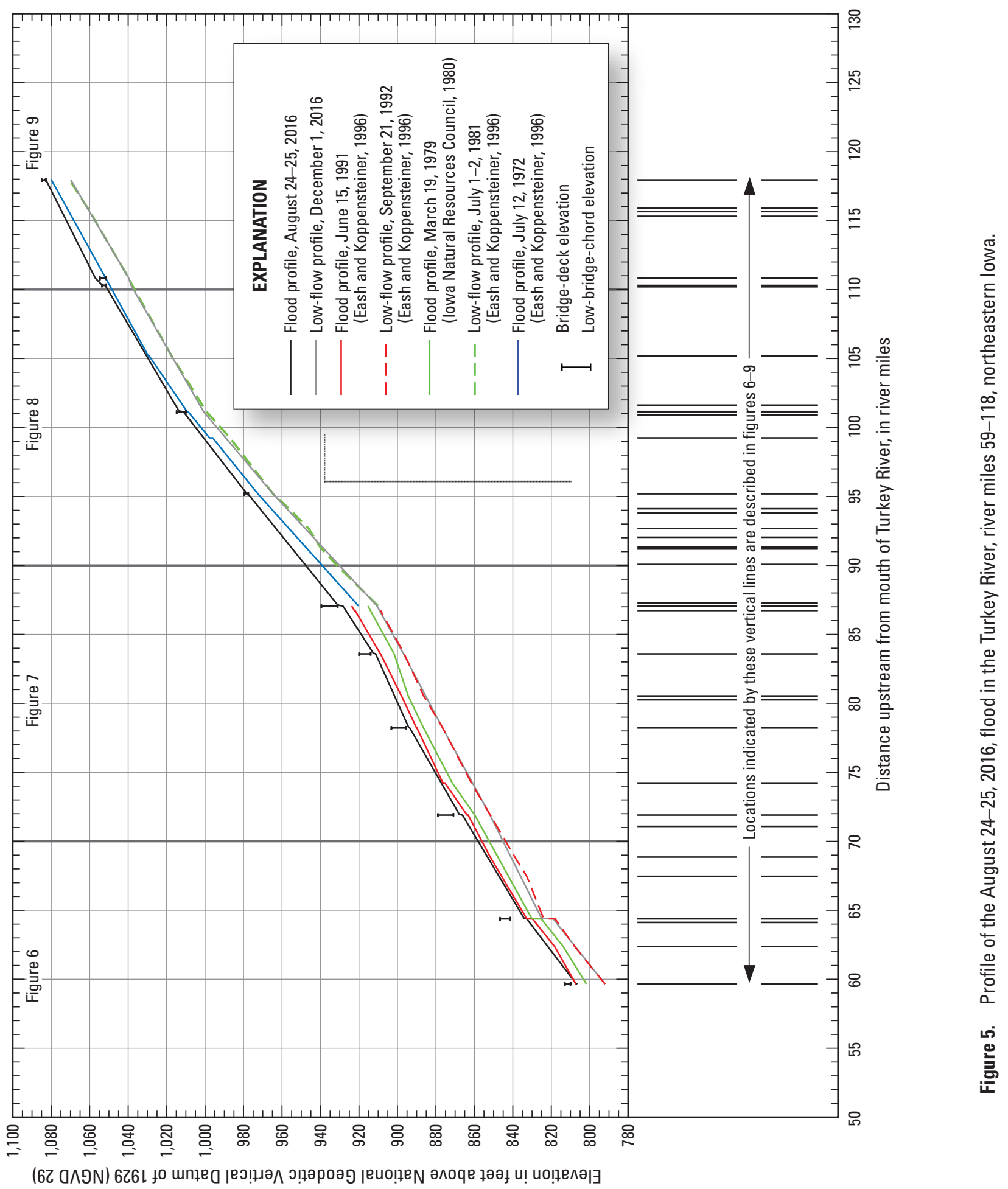




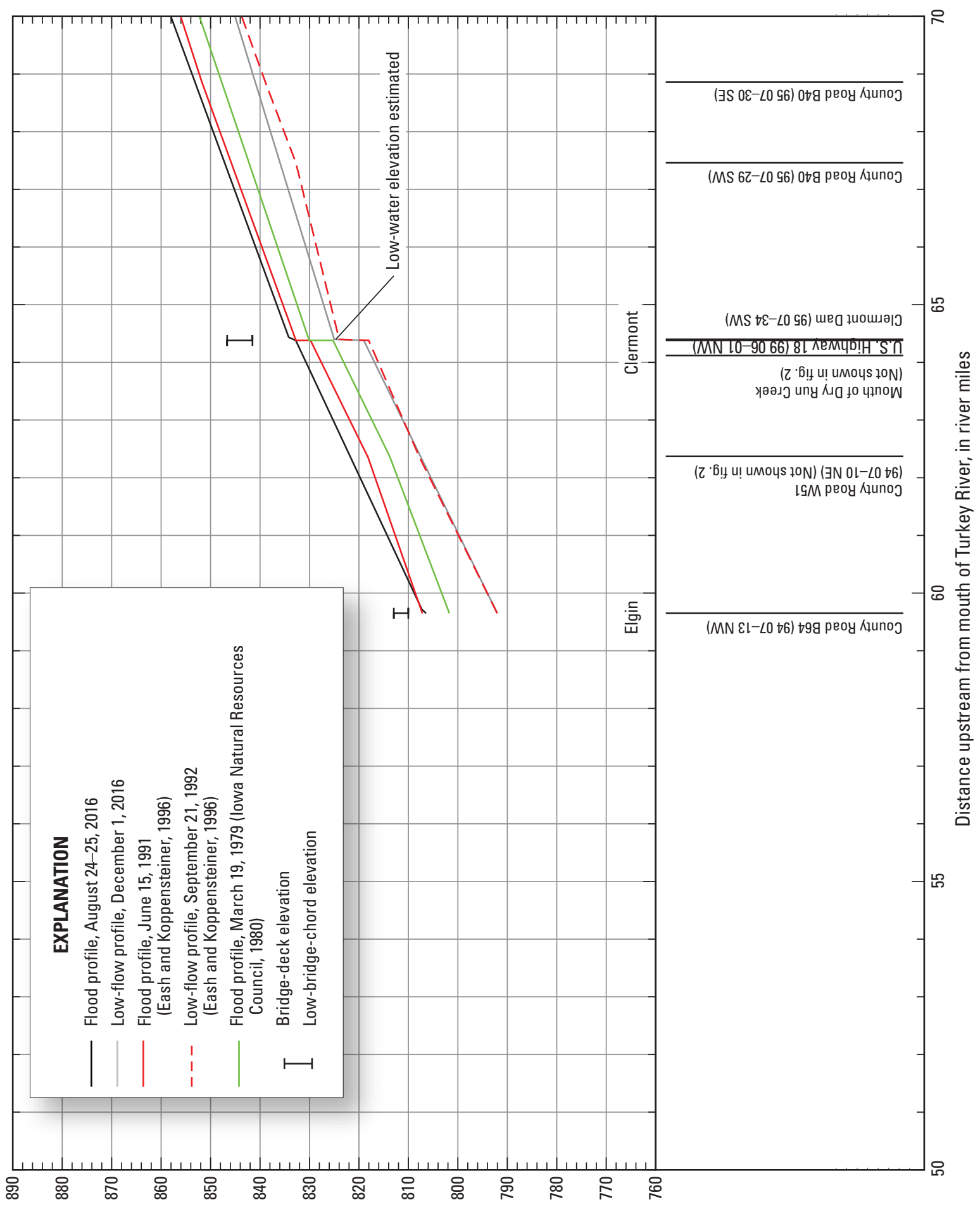

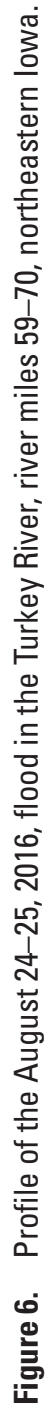

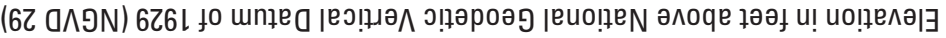




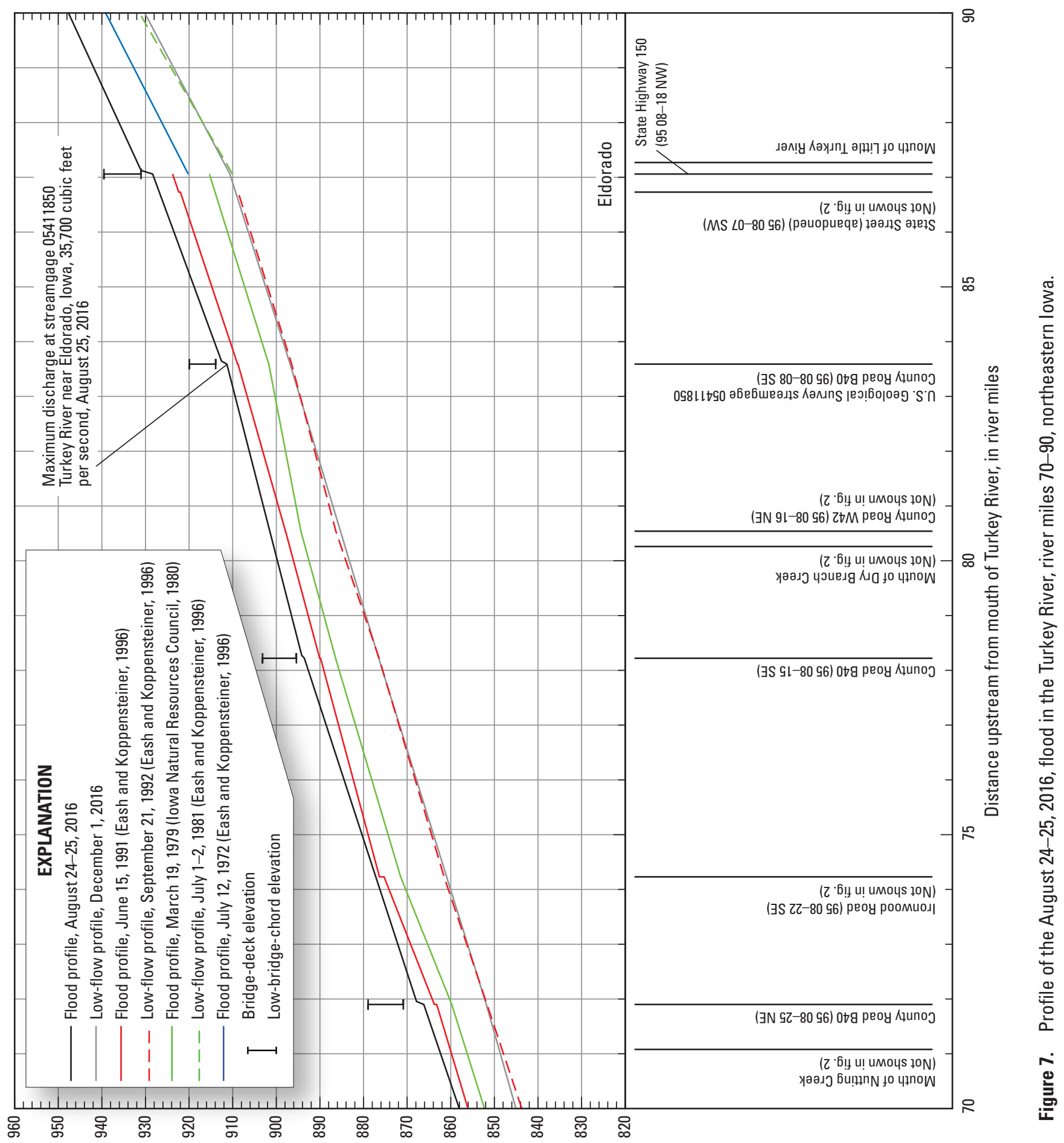

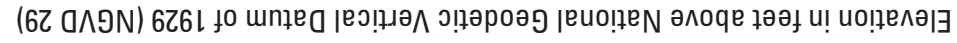




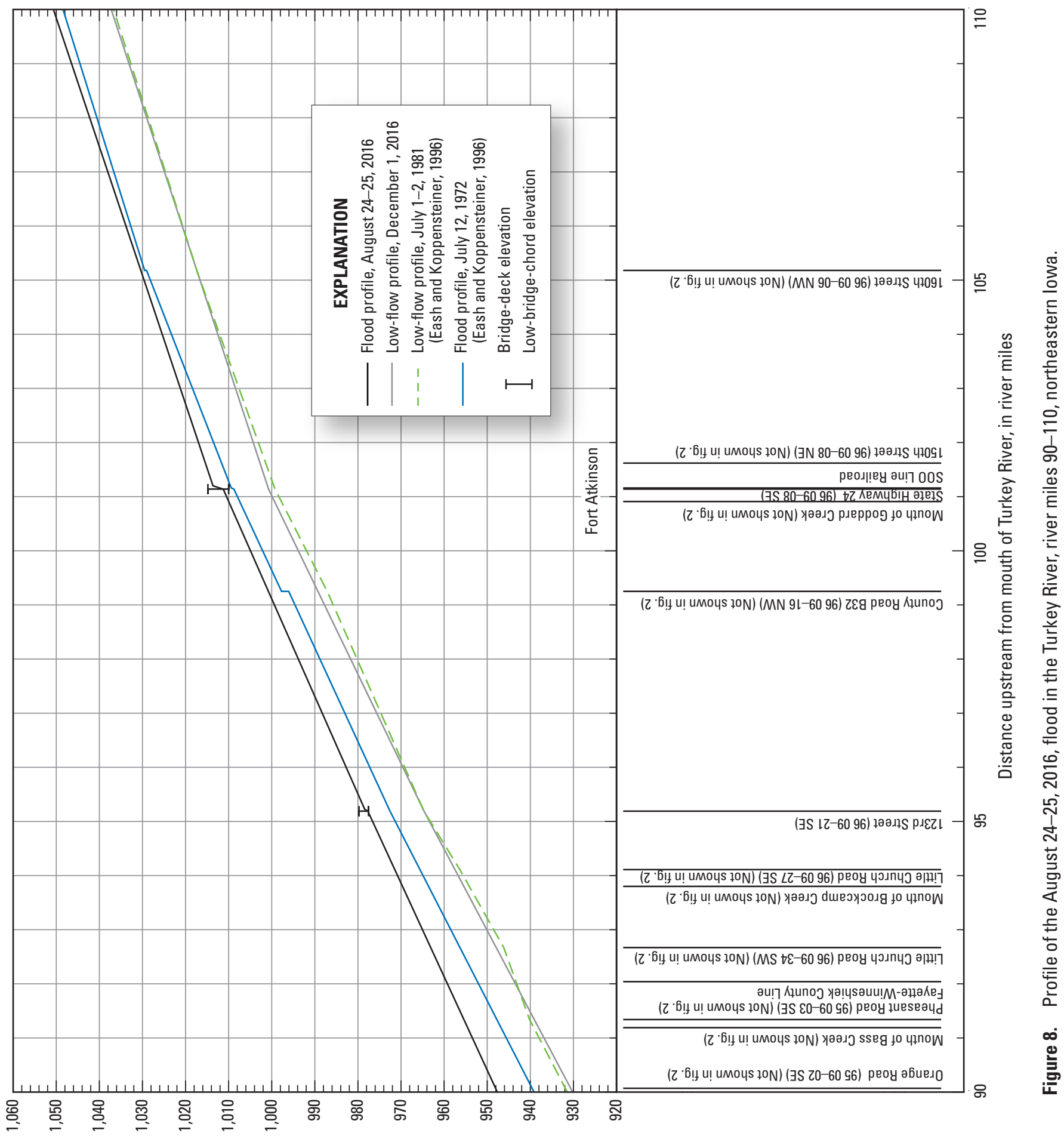

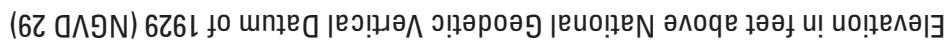




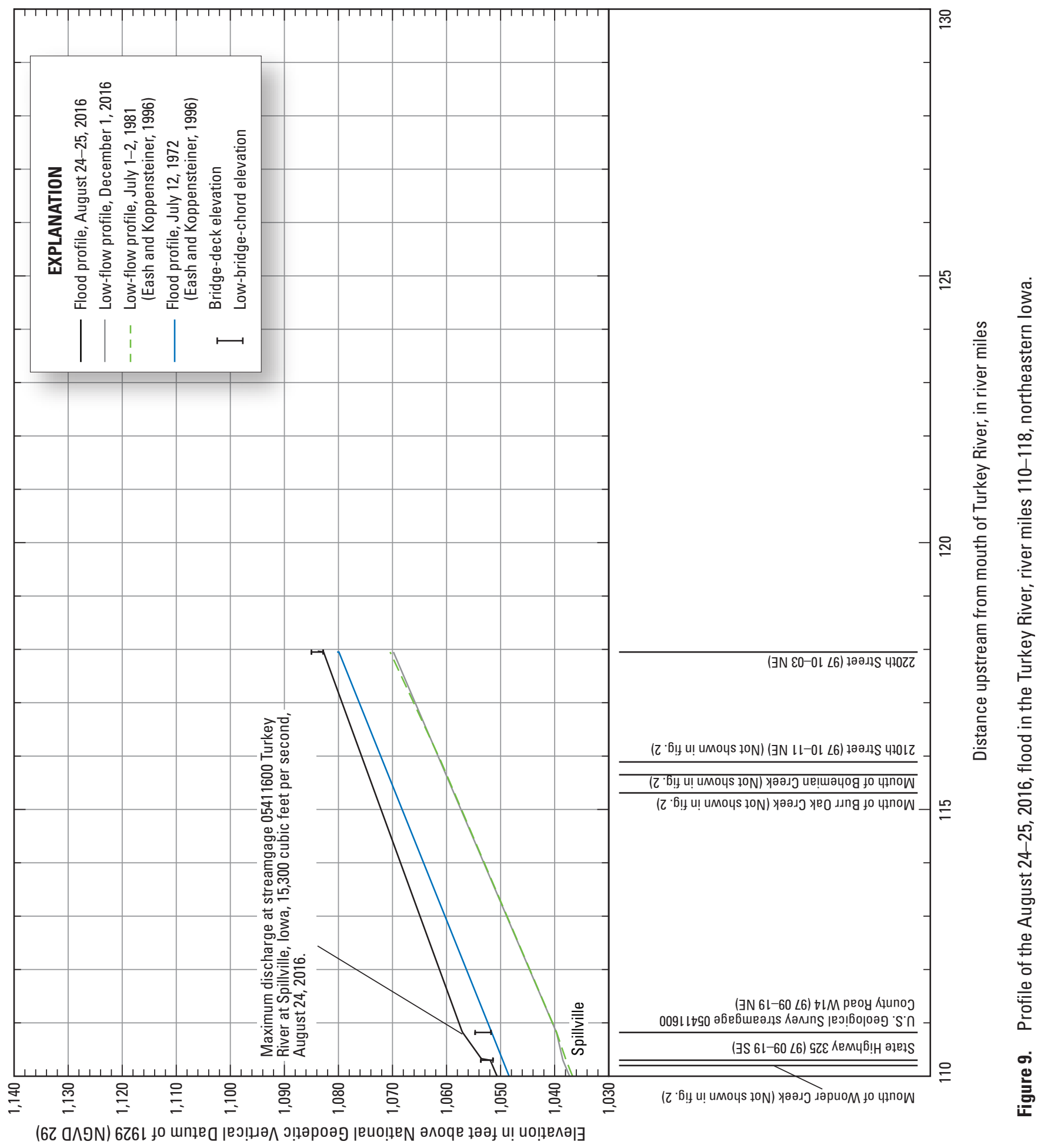




\section{Summary}

The Upper Iowa River in northeastern Iowa flooded throughout the lower part of the basin on August 24-25, 2016, following severe thunderstorm activity over northeastern Iowa. Within the Upper Iowa River Basin, the rainfall amount at Decorah, Iowa, was about 8 inches (in.) for the 24-hour period ending at 4 p.m. on August 24; at Cresco, Iowa, near the boundary of the Upper Iowa River and Turkey River Basins, rainfall was about 6 in. for the 24-hour period ending at 7 a.m. on August 24. One location about 5 miles southeast of Decorah recorded more than 8 in. overnight on August 23. Along the profiled reach, a maximum peak-of-record discharge of 38,000 cubic feet per second $\left(\mathrm{ft}^{3} / \mathrm{s}\right)$ at streamgage 05388250 Upper Iowa River near Dorchester, Iowa, occurred on August 24, 2016. The annual exceedance probability (AEP) range of the peak discharge is $0.2-1$ percent. High-water marks measured at six locations along the lower reach of the Upper Iowa River were presented in a flood profile between State Highway 26 near the mouth at the Mississippi River and State Highway 76 south of Dorchester, Iowa. The length of the profile is 15 river miles.

The Turkey River in northeastern Iowa flooded throughout much of the basin on August 24-25, 2016, following severe thunderstorm activity over northeastern Iowa. Within the Turkey River Basin, the rainfall amount at Cresco was about 6 in., at Protivin rainfall was almost 7 in., and just over 6 in. of rain fell at Fort Atkinson for the 24-hour period ending at 7 a.m. on August 24, 2016. Along the profiled reach, a maximum peakof-record discharge of 15,300 ft $3 / \mathrm{s}$ at streamgage 05411600 Turkey River at Spillville, Iowa, occurred on August 24, 2016. The AEP range of the peak discharge is 1-2 percent. The peak discharge of $35,700 \mathrm{ft}^{3} / \mathrm{s}$ at streamgage 05411850 Turkey River near Eldorado on August 25, 2016, was the second highest peak discharge of record with an AEP range of the peak discharge of $0.2-1$ percent. High-water marks measured at 11 locations along the Turkey River were presented in a flood profile between County Road B64 in Elgin and 220th Street northwest of Spillville, Iowa, a distance of 58 river miles.

\section{References Cited}

Cohn, T.A., Berenbrock, Charles, Kiang, J.E., and Mason, R.R., Jr., 2012, Calculating weighted estimates of peak streamflow statistics: U.S. Geological Survey Fact Sheet 2012-3038, 4 p. [Also available at https://pubs.usgs.gov/ fs/2012/3038/pdf/fs2012-3038.pdf.]

Eash, D.A., and Koppensteiner, B.A., 1996, Floods of July 12, 1972, March 19, 1979, and June 15, 1991, in the Turkey River Basin, northeast Iowa: U.S. Geological Survey Open-File Report 96-560, 55 p. with app. [Also available at https://pubs.usgs.gov/of/1996/0560/report.pdf.]

Eash, D.A., 2001, Techniques for estimating flood-frequency discharges for streams in Iowa: U.S. Geological Survey Water-Resources Investigations Report 00-4233, 88 p. [Also available at https://pubs.er.usgs.gov/publication/ wri004233.]

Eash, D.A., 2003, Main-channel slopes of selected streams in Iowa for estimation of flood-frequency discharges: U.S. Geological Survey Water-Resources Investigations Report 03-4120, 215 p. [Also available at https://pubs.er.usgs.gov/ publication/wri034120.]

Eash, D.A., 2014, Summary of U.S. Geological Survey reports documenting flood profiles of streams in Iowa, 1963-2012: U.S. Geological Survey Scientific Investigations Report 2014-5085, 32 p. [Also available at https://pubs.usgs.gov/ $\operatorname{sir} / 2014 / 5085 /$.

Federal Emergency Management Agency, 2016, Iowa severe storms, straight-line winds, and flooding (DR-4281), accessed June 20, 2017, at https://www.fema.gov/disaster/4281.

Fischer, E.E., and Eash, D.A., 2010, Flood of June 8-9, 2008, Upper Iowa River, Northeast Iowa: U.S. Geological Survey Open-File Report 2010-1087, 17 p. with app. [Also available at https://pubs.usgs.gov/of/2010/1087/pdf/OF20101087.pdf.]

Hillaker, H.J., 2016a, Iowa Annual Weather Summary - 2016: Des Moines, Iowa, Iowa Department of Agriculture and Land Stewardship, accessed May 19, 2017, at http://www. iowaagriculture.gov/climatology/weatherSummaries/2016/ fas2016.pdf.

Hillaker, H.J., 2016b, Iowa climate review August 2016: Des Moines, Iowa, Department of Agriculture and Land Stewardship, v. 30, no. 8, 21 p., accessed May 19, 2017, at http:/www.iowaagriculture.gov/climatology/ClimateReview/2016/IowaClimateReview201608.pdf. 
Holmes, R.R., Jr., and Dinicola, K., 2010, 100-year flood-It's all about chance: U.S. Geological Survey General Information Product 106, 4 p., accessed September 25, 2017 , at http://pubs.usgs.gov/gip/106/pdf/100-year-flood-handout-042610.pdf.

Horick, P.J., 1989, Water resources of northeast Iowa with a section on Surface-water resources by P.J. Soenksen: Iowa Department of Natural Resources Water Atlas No. 8, 133 p. [Also available at https://s-iihr34.iihr.uiowa.edu/publications/uploads/WA-08.pdf.]

Interagency Advisory Committee on Water Data, 1982, Guidelines for determining flood flow frequency: Hydrology Subcommittee Bulletin 17B, 28 p. and app.

Iowa Natural Resources Council, 1958, An inventory of water resources and water problems, northeastern Iowa River Basins: Des Moines, Iowa, Bulletin No. 7, 74 p.

Iowa Natural Resources Council, 1980, Turkey/Volga River flood of March 19, 1979: Des Moines, Iowa, 25 p.

Larimer, O.J., 1957, Drainage areas of Iowa streams: Iowa Highway Research Board Bulletin No. 7 (reprinted 1974), 439 p. [Also available at http://www.iowadot.gov/ research/reports/Year/2003andolder/fullreports/HR-29\%20 FINAL\%20Drainage\%20Areas\%20of\%20Iowa\%20 Streams.pdf.]

Love, Orlan, 2016, September 1, Last week's Iowa flood damage estimated at $\$ 5$ million and growing. Damage to homes from last week's sudden flooding still being tabulated: Cedar Rapids-Iowa City Gazette, accessed September 14, 2017, at http://www.thegazette.com/subject/news/government/last-weeks-iowa-flood-damage-estimated-at-5-millionand-growing-20160901.

National Centers for Environmental Information, National Oceanic and Atmospheric Administration (NOAA), 2016, Storm Events Database, accessed June 19, 2017, at https://www.ncdc.noaa.gov/stormevents/choosedates. jsp?statefips $=19 \% 2 \mathrm{CIOWA}$.

National Weather Service (NWS) and National Oceanic and Atmospheric Administration (NOAA), 2016a, Flooding of August 23-25, 2016, accessed June 19, 2017, at http:/www. weather.gov/arx/aug2416.

National Weather Service (NWS) and National Oceanic and Atmospheric Administration (NOAA), 2016b, Advanced Hydrologic Prediction Service, accessed February 24, 2017, at http://water.weather.gov/ahps2/hydrograph. php wfo $=$ arx \&gage $=$ dchi4\&hydro_type $=2$.
National Weather Service (NWS) and National Oceanic and Atmospheric Administration (NOAA), 2016c, Advanced Hydrologic Prediction Service, accessed February 24, 2017, at http://water.weather.gov/ahps2/hydrograph. php wfo=arx\&gage $=$ spli4\&hydro_type $=2$.

National Weather Service (NWS) and National Oceanic and Atmospheric Administration (NOAA), 2016d, Advanced Hydrologic Prediction Service, accessed February 24, 2017, at http://water.weather.gov/ahps2/hydrograph. php $? w f o=a r x \& g a g e=e d r i 4 \&$ hydro_type $=2$.

National Weather Service (NWS) and National Oceanic and Atmospheric Administration (NOAA), 2017, Hydrologic Information on the Web, A Manual for Users, accessed July 21, 2017, at http://www.nws.noaa.gov/os/water/ahps/ resources/Hydrologic_Web_Products_Manual.pdf.

Prior, J.C., 1991, Landforms of Iowa: Iowa City, University of Iowa Press, 154 p.

U.S. Geological Survey (USGS), 2008, Peak streamflow for the Nation: National Water Information System (NWISWeb), accessed January 30, 2017, at https://nwis. waterdata.usgs.gov/usa/nwis/peak/?site_no $=05411850$.

U.S. Geological Survey (USGS), 2016a, Water-year summary for site 05388250: National Water Information System (NWISWeb), accessed January 30, 2017, at https://waterdata.usgs.gov/ia/nwis/wys_rpt/?site_no $=05388250$.

U.S. Geological Survey (USGS), 2016b, Water-year summary for site 05411600: National Water Information System (NWISWeb), accessed January 30, 2017, at https://waterdata.usgs.gov/ia/nwis/wys_rpt/?site_no $=05411600$.

U.S. Geological Survey (USGS), 2016c, Water-year summary for site 05411850: National Water Information System (NWISWeb), accessed January 30, 2017, at https://waterdata.usgs.gov/ia/nwis/wys_rpt/?site_no $=05411850$.

U.S. Geological Survey (USGS), 2017a, WaterWatch: National Water Information System (NWISWeb), accessed September 12, 2017, at https://waterdata.usgs.gov/nwisweb/ get_ratings?file_type $=$ exsa\&site_no $=05388250$.

U.S. Geological Survey (USGS), 2017b, WaterWatch: National Water Information System (NWISWeb), accessed September 12, 2017, at https:/waterdata.usgs.gov/nwisweb/ get_ratings?file_type $=$ exsa\&site_no $=05411600$.

U.S. Geological Survey (USGS), 2017c, WaterWatch: National Water Information System (NWISWeb), accessed September 12, 2017, at https://waterdata.usgs.gov/nwisweb/ get_ratings?file_type $=$ exsa\&site_no $=05411850$.

U.S. Geological Survey (USGS), 2017d, National hydrography dataset, accessed October 19, 2017, at https://nhd.usgs. gov/NHD_High_Resolution.html. 


\section{Appendix 1. List of Bench Marks and Reference Points}

The U.S. Geological Survey (USGS) used the bench marks and reference points listed in table 1-1 to facilitate measuring the elevations of high-water marks, low-flow water surfaces, bridge decks, and bridge low chords. Temporary bench marks were established at sites where bench marks were not available. In general, bench marks are points that were specifically designed to mark an elevation, such as USGS elevation disks and Iowa Department of Transportation bench marks (roundtop rods embedded in concrete at one or more corners of a bridge). Temporary bench marks are marks such as chiseled squares, chiseled arrows, or file marks. Reference points were established above water on the downstream side of each bridge to facilitate measuring low-flow water-surface elevations. Users are cautioned that the bench marks and reference points used for this flood profile might have been altered or destroyed since being used in 2016.

The bench marks and reference points are listed in upstream order. Each bench mark is identified by an index number composed of the Public Land Survey System township, range, section number, and quarter section for each bench-mark location. For example, T100N R4W 15 SE means "township 100 north, range 4 west, section 15 , southeast quarter section." Where two or more bench marks/reference points are in the same location, the points are distinguished by a sequence number in parentheses. "Right" and "left" in the descriptions refer to the side of the river determined as an observer looks downstream.

A combination of Global Positioning System (GPS) technology and differential leveling was used to measure benchmark/reference-point elevations at each site except where noted otherwise in table 1-1. The GPS data were collected by the USGS using Real Time Kinematic (RTK) surveys. The RTK surveys of GPS data were processed using the IaRTN SmartNet, a Global Navigation Satellite System (GNSS) reference station network service provided by Iowa Department of Transportation and Leica Geosystems (Iowa Department of Transportation, IaRTN SmartNet, 2016). The quality of the RTK GPS data are based on an average of multiple sets of GPS data collected using satellite configurations spaced at least 30 minutes apart and on comparisons of elevations between RTK GPS surveys of GPS bench marks and published elevations.

Table 1-1. Bench marks and reference points used in the Upper lowa River and Turkey River flood profiles, flood of August 24-25, 2016, northeastern lowa.

[Bench marks and reference points are listed in upstream order. Where two or more bench marks/reference points are in the same location, the points are distinguished by a sequence number in parentheses. NGVD 29, National Geodetic Vertical Datum of 1929; TBM, temporary bench mark; GPS, Geographical Positioning System; RP, reference point; BM, bench mark; DOT, Department of Transportation]

\begin{tabular}{|c|c|c|c|c|c|}
\hline $\begin{array}{l}\text { Public Land Survey System } \\
\text { (township, range, section, } \\
\text { quarter section, sequence } \\
\text { number at same location) }\end{array}$ & $\begin{array}{l}\text { Mark } \\
\text { classification }\end{array}$ & Location & Mark & $\begin{array}{l}\text { Elevation } \\
\text { (feet above } \\
\text { NGVD 1929) }\end{array}$ & $\begin{array}{l}\text { Elevation deter- } \\
\text { mination method }\end{array}$ \\
\hline \multicolumn{6}{|c|}{ Upper lowa River Basin } \\
\hline T100N R4W 15 SE (1) & TBM & $\begin{array}{l}\text { About } 2 \text { miles south of New Albin, on State Highway } 26 \text { bridge over the } \\
\text { main channel (south side of valley), on left upstream wingwall. }\end{array}$ & $\begin{array}{l}\text { Chiseled } \\
\text { square }\end{array}$ & 647.03 & GPS \\
\hline T100N R4W 15 SE (2) & $\mathrm{RP}$ & $\begin{array}{l}\text { About } 2 \text { miles south of New Albin, on State Highway } 26 \text { bridge over } \\
\text { the main channel (south side of valley), on downstream side of bridge } \\
\text { between } 23 \text { rd and } 24 \text { th vertical supports from left end of bridge. }\end{array}$ & $\begin{array}{l}\text { Chiseled } \\
\text { arrow }\end{array}$ & 647.20 & GPS \\
\hline T100N R4W 28 NW (1) & TBM & $\begin{array}{l}\text { About } 3 \text { miles southwest of New Albin, on Morgan Bridge Road east } \\
\text { of intersection with Iowa River Drive (County Road A26), on right } \\
\text { downstream concrete rail. }\end{array}$ & $\begin{array}{l}\text { Chiseled } \\
\text { square }\end{array}$ & 654.14 & GPS \\
\hline T100N R4W 28 NW (2) & $\mathrm{RP}$ & $\begin{array}{l}\text { About } 3 \text { miles southwest of New Albin, on Morgan Bridge Road east of } \\
\text { intersection with Iowa River Drive (County Road A26), on downstream } \\
\text { concrete rail near center of bridge. }\end{array}$ & $\begin{array}{l}\text { Three file } \\
\text { marks }\end{array}$ & 654.88 & GPS \\
\hline T100N R5W 35 SE (1) & $\mathrm{BM}$ & $\begin{array}{l}\text { About } 6 \text { miles southwest of New Albin, on Lycurgus Road bridge } \\
\text { adjacent to the intersection of Iowa River Drive (County Road A26) } \\
\text { and Lycurgus Road, on left downstream wingwall. }\end{array}$ & $\begin{array}{l}\text { Round-top } \\
\text { rod embedded } \\
\text { in concrete }\end{array}$ & 676.44 & GPS \\
\hline T100N R5W 35 SE (2) & $\mathrm{RP}$ & $\begin{array}{l}\text { About } 6 \text { miles southwest of New Albin, on Lycurgus Road bridge } \\
\text { adjacent to the intersection of Iowa River Drive (County Road A26) } \\
\text { and Lycurgus Road, on downstream barrier wall near third barrier-wall } \\
\text { seam from left end of bridge, about } 4 \mathrm{ft} \text { right of seam. }\end{array}$ & $\begin{array}{l}\text { Chiseled } \\
\text { arrow }\end{array}$ & 673.21 & GPS \\
\hline T99N R6W 1 NW & $\mathrm{BM}$ & $\begin{array}{l}\text { About } 3.5 \text { miles south of Dorchester, site of streamgage } 05388250 \text { Upper } \\
\text { Iowa River near Dorchester, Iowa, on State Highway } 76 \text { bridge, on right } \\
\text { upstream concrete guard rail. }\end{array}$ & $\begin{array}{c}\text { Iowa DOT } \\
\text { bench mark }\end{array}$ & 693.01 & $\begin{array}{c}\text { Streamgage } \\
\text { elevation } \\
\text { data }\end{array}$ \\
\hline \multicolumn{6}{|c|}{ Turkey River Basin } \\
\hline T94N R7W 13 NW (1) & TBM & $\begin{array}{l}\text { About } 0.1 \text { miles east of Elgin on County Road B64, on left downstream } \\
\text { wingpost. }\end{array}$ & $\begin{array}{l}\text { Chiseled } \\
\text { square }\end{array}$ & 816.02 & GPS \\
\hline T94N R7W 13 NW (2) & $\mathrm{RP}$ & $\begin{array}{l}\text { About } 0.1 \text { miles east of Elgin on County Road B64, 5th drainhole from } \\
\text { left side of bridge on downstream curb. }\end{array}$ & $\begin{array}{l}\text { Chiseled } \\
\text { arrow }\end{array}$ & 814.08 & GPS \\
\hline
\end{tabular}


Table 1-1. Bench marks and reference points used in the Upper lowa River and Turkey River flood profiles, flood of August 24-25, 2016, northeastern lowa.-Continued

[Bench marks and reference points are listed in upstream order. Where two or more bench marks/reference points are in the same location, the points are distinguished by a sequence number in parentheses. NGVD 29, National Geodetic Vertical Datum of 1929; TBM, temporary bench mark; GPS, Geographical Positioning System; RP, reference point; BM, bench mark; DOT, Department of Transportation]

\begin{tabular}{|c|c|c|c|c|c|}
\hline $\begin{array}{l}\text { Public Land Survey System } \\
\text { (township, range, section, } \\
\text { quarter section, sequence } \\
\text { number at same location) }\end{array}$ & $\begin{array}{l}\text { Mark } \\
\text { classification }\end{array}$ & Location & Mark & $\begin{array}{c}\text { Elevation } \\
\text { (feet above } \\
\text { NGVD 1929) }\end{array}$ & $\begin{array}{l}\text { Elevation deter- } \\
\text { mination method }\end{array}$ \\
\hline \multicolumn{6}{|c|}{ Turkey River Basin-Continued } \\
\hline T95N R7W 34 SW (1) & TBM & $\begin{array}{l}\text { On the southwestern side of Clermont, on U.S. Highway } 18 \text { bridge, on } \\
\text { top of right downstream guardrail. }\end{array}$ & $\begin{array}{l}\text { Chiseled } \\
\text { cross }\end{array}$ & 849.49 & GPS \\
\hline T95N R7W 34 SW (2) & $\mathrm{RP}$ & $\begin{array}{l}\text { On the southwestern side of Clermont, on U.S. Highway } 18 \text { bridge, on } \\
\text { top of downstream guardrail, one foot to the right of wire weight. }\end{array}$ & $\begin{array}{l}\text { Chiseled } \\
\text { arrow }\end{array}$ & 849.70 & GPS \\
\hline T95N R8W 25 NE (1) & TBM & $\begin{array}{l}\text { About } 3.9 \text { miles northwest of Clermont on County Road B40 bridge } \\
\text { over Turkey River, on left upstream corner of wingpost. }\end{array}$ & $\begin{array}{l}\text { Chiseled } \\
\text { square }\end{array}$ & 878.68 & $\begin{array}{c}\text { Historic } \\
\text { surveyed level } \\
\text { line from 1st or } \\
\text { 2nd order BM }\end{array}$ \\
\hline T95N R8W 25 NE (2) & $\mathrm{RP}$ & $\begin{array}{l}\text { About } 3.9 \text { miles northwest of Clermont on County Road B } 40 \text { bridge } \\
\text { over Turkey River, } 8 \text { feet right of third drainhole from left downstream } \\
\text { side of bridge. }\end{array}$ & $\begin{array}{l}\text { Chiseled } \\
\text { arrow }\end{array}$ & 880.96 & $\begin{array}{l}\text { Surveyed level } \\
\text { line from TBM }\end{array}$ \\
\hline T95N R8W 15 SE (1) & TBM & $\begin{array}{l}\text { Approximately } 3.5 \text { miles southeast of Eldorado on County Road B40 } \\
\text { bridge over Turkey River, on top of concrete guardrail on left down- } \\
\text { stream end of bridge. }\end{array}$ & $\begin{array}{l}\text { Chiseled } \\
\text { square }\end{array}$ & 902.81 & $\begin{array}{c}\text { Historic } \\
\text { surveyed level } \\
\text { line from 1st or } \\
\text { 2nd order BM }\end{array}$ \\
\hline T95N R8W 15 SE (2) & $\mathrm{RP}$ & $\begin{array}{l}\text { About } 3.5 \text { miles southeast of Eldorado on County Road B40 bridge over } \\
\text { Turkey River, left of } 10 \text { th concrete section from right downstream } \\
\text { wingwall. }\end{array}$ & $\begin{array}{l}\text { Chiseled } \\
\text { square }\end{array}$ & 907.31 & $\begin{array}{l}\text { Surveyed level } \\
\text { line from TBM }\end{array}$ \\
\hline T95N R8W 8 SE (1) & TBM & $\begin{array}{l}\text { About } 1.4 \text { miles east of Eldorado, site of streamgage } 05411850 \text { Turkey } \\
\text { River near Eldorado, on County Road B40 bridge over Turkey River, } \\
\text { on top of right downstream wingwall. }\end{array}$ & $\begin{array}{l}\text { Chiseled } \\
\text { cross }\end{array}$ & 922.99 & $\begin{array}{l}\text { Streamgage } \\
\text { elevation } \\
\text { data }\end{array}$ \\
\hline T95N R8W 18 NW (1) & TBM & $\begin{array}{l}\text { At Eldorado, on State Highway } 150 \text { bridge over Turkey River, on left } \\
\text { downstream abutment and } 10 \text { feet right of wingwall curb. }\end{array}$ & $\begin{array}{l}\text { Chiseled } \\
\text { square }\end{array}$ & 938.16 & $\begin{array}{c}\text { Historic } \\
\text { surveyed level } \\
\text { line from 1st or } \\
\text { 2nd order BM }\end{array}$ \\
\hline T95N R8W 18 NW (2) & RP & $\begin{array}{l}\text { At Eldorado, on State Highway } 150 \text { bridge over Turkey River, on 19th } \\
\text { metal plate of old guardrail from right downstream end of bridge. }\end{array}$ & $\begin{array}{l}\text { Three file } \\
\text { marks }\end{array}$ & 940.93 & $\begin{array}{l}\text { Surveyed level } \\
\text { line from TBM }\end{array}$ \\
\hline T96N R9W 21 SE (1) & TBM & $\begin{array}{l}\text { About } 2.6 \text { miles southeast of Fort Atkinson, on 123rd Street bridge } \\
\text { over Turkey River, on left downstream I-beam of truss bridge on left } \\
\text { most rivet. }\end{array}$ & $\begin{array}{l}\text { Chiseled } \\
\text { cross }\end{array}$ & 979.28 & GPS \\
\hline T96N R9W 21 SE (2) & RP & $\begin{array}{l}\text { About } 2.6 \text { miles southeast of Fort Atkinson, on } 123 \text { rd Street bridge over } \\
\text { Turkey River, on downstream side of bridge } 15 \text { feet right of the center } \\
\text { bridge pier and of "V" formed by truss bridge. }\end{array}$ & $\begin{array}{l}\text { Two file } \\
\text { marks }\end{array}$ & 983.63 & GPS \\
\hline T96N R9W 8 SE (1) & $\mathrm{BM}$ & $\begin{array}{l}\text { At Fort Atkinson, on State Highway } 24 \text { bridge over Turkey River, on top } \\
\text { of right downstream concrete guardrail. }\end{array}$ & $\begin{array}{l}\text { Iowa DOT } \\
\text { bench mark }\end{array}$ & $1,017.78$ & GPS \\
\hline T96N R9W 8 SE (2) & $\mathrm{RP}$ & $\begin{array}{l}\text { At Fort Atkinson, on State Highway } 24 \text { bridge over Turkey River, above } \\
\text { first drain hole from right downstream side of bridge on } \\
\text { concrete guardrail. }\end{array}$ & $\begin{array}{l}\text { Chiseled } \\
\text { square/arrow }\end{array}$ & $1,017.82$ & GPS \\
\hline T97N R9W 19 SE (1) & $\mathrm{BM}$ & $\begin{array}{l}\text { At Spillville, on State Highway } 325 \text { bridge over Turkey River, on left } \\
\text { upstream wingwall. }\end{array}$ & $\begin{array}{l}\text { Winneshiek } \\
\text { County tablet }\end{array}$ & $1,056.93$ & GPS \\
\hline T97N R9W 19 SE (2) & $\mathrm{RP}$ & $\begin{array}{l}\text { At Spillville, on State Highway } 325 \text { bridge over Turkey River, in the } \\
\text { middle of the upstream concrete guardrail. }\end{array}$ & $\begin{array}{l}\text { Chiseled } \\
\text { square }\end{array}$ & $1,056.46$ & GPS \\
\hline T97N R9W 19 NE (1) & TBM & $\begin{array}{l}\text { At Spillville, site of streamgage } 05411600 \text { Turkey River at Spillville, } \\
\text { on County Road W14 bridge over Turkey River, on top of right down- } \\
\text { stream wingwall. }\end{array}$ & $\begin{array}{l}\text { Chiseled } \\
\text { square }\end{array}$ & $1,057.56$ & $\begin{array}{l}\text { Streamgage } \\
\text { elevation } \\
\text { data }\end{array}$ \\
\hline T97N R10W 03 NE (1) & TBM & $\begin{array}{l}\text { About } 4.5 \text { miles northwest of Spillville, on } 220 \text { th Street bridge over } \\
\text { Turkey River, on right downstream corner of bridge deck on down- } \\
\text { stream landward rivet. }\end{array}$ & $\begin{array}{l}\text { Chiseled } \\
\text { cross }\end{array}$ & $1,084.64$ & $\begin{array}{c}\text { Historic } \\
\text { surveyed level } \\
\text { line from 1st or } \\
\text { 2nd order BM }\end{array}$ \\
\hline T97N R10W 03 NE (2) & $\mathrm{RP}$ & $\begin{array}{l}\text { About } 4.5 \text { miles northwest of Spillville, on } 220 \text { th Street bridge over } \\
\text { Turkey River, about } 50 \text { feet from left downstream side of bridge on top } \\
\text { of fourth vertical guardrail post. }\end{array}$ & $\begin{array}{l}\text { Three file } \\
\text { marks }\end{array}$ & $1,088.41$ & $\begin{array}{l}\text { Surveyed level } \\
\text { line from TBM }\end{array}$ \\
\hline
\end{tabular}




\section{References}

Iowa Department of Transportation, IaRTN SmartNet, 2016, accessed July 6, 2017, available online at https://iowadot. gov/rtn and http://smartnet.iartn.com/. 
For additional information contact:

Director, Central Midwest Water Science Center U.S. Geological Survey

400 S. Clinton Street

lowa City, IA 52240

Publishing support provided by the

Madison and Sacramento Publishing Service Centers 

